University of Nebraska - Lincoln

DigitalCommons@University of Nebraska - Lincoln

PREPUBERTAL CHANGES IN PLASMA FSH AND INHIBIN IN HOLSTEIN BULL CALVES: RESPONSES TO CASTRATION AND(OR) ESTRADIOL

\author{
R. D. MacDonald \\ Pennsylvania State University \\ D. R. Deaver \\ Pennsylvania State University - Main Campus \\ B. D. Schanbacher \\ USDA-ARS
}

Follow this and additional works at: https://digitalcommons.unl.edu/usdaarsfacpub

Part of the Agricultural Science Commons

\author{
MacDonald, R. D.; Deaver, D. R.; and Schanbacher, B. D., "PREPUBERTAL CHANGES IN PLASMA FSH AND \\ INHIBIN IN HOLSTEIN BULL CALVES: RESPONSES TO CASTRATION AND(OR) ESTRADIOL" (1991). \\ Publications from USDA-ARS / UNL Faculty. 779. \\ https://digitalcommons.unl.edu/usdaarsfacpub/779
}

This Article is brought to you for free and open access by the U.S. Department of Agriculture: Agricultural Research Service, Lincoln, Nebraska at DigitalCommons@University of Nebraska - Lincoln. It has been accepted for inclusion in Publications from USDA-ARS / UNL Faculty by an authorized administrator of DigitalCommons@University of Nebraska - Lincoln. 


\title{
PREPUBERTAL CHANGES IN PLASMA FSH AND INHIBIN IN HOLSTEIN BULL CALVES: RESPONSES TO CASTRATION AND(OR) ESTRADIOL1
}

\author{
R. D. MacDonald ${ }^{2}$, D. R. Deaver ${ }^{2,3}$ and B. D. Schanbacher $r^{4,5}$ \\ Pennsylvania State University, University Park, PA 16802 and \\ U.S. Department of Agriculture, Clay Center, NE 68933 \\ ABSTRACT
}

\begin{abstract}
The objectives of two studies were to determine 1) whether plasma concentrations of inhibin (INH) changed with age in prepubertal bulls and whether these changes were related to changes in FSH, testosterone or testis length; and 2) whether castration and(or) estradiol implants affected plasma concentrations of INH and FSH. In Exp. 1, plasma INH remained constant from 4 until 8 wk of age then increased from $120 \mathrm{pM}$ to $202 \mathrm{pM}$ between 8 and $12 \mathrm{wk}$. Thereafter, INH decreased to $90 \mathrm{pM}$ by $36 \mathrm{wk}$. Between 4 and 10 wk, plasma FSH increased from .32 to $.43 \mathrm{ng} / \mathrm{ml}$, apparently increasing before the initial rise in plasma INH. Between 10 and 12 wk, FSH declined from .43 to $.33 \mathrm{ng} / \mathrm{ml}$. After 12 wk, FSH increased as INH decreased. Initial increases in testis length and concentrations of plasma testosterone occurred at 14 wk coincident with the second rise in FSH. In Exp. 2, bull calves were either left intact, castrated, castrated and implanted with estradiol, or left intact and implanted with estradiol at $7.5 \mathrm{wk}$ of age. Castration decreased concentrations of INH and increased concentrations of FSH. Castrated calves implanted with estradiol had decreased concentrations of both INH and FSH. Intact bulls implanted with estradiol had decreased concentrations of FSH relative to intact unimplanted bulls; however, concentrations of INH did not display the age-related changes observed in intact, unimplanted bulls. In summary, age-related changes in plasma INH and FSH occur in bulls. Furthermore, plasma concentrations of INH and FSH increased before changes in gonadal size were detected. The bovine testis may be a major source of circulating $\mathbf{N H}$ because castration decreased concentrations of plasma INH.
\end{abstract}

Key Words: Bulls, Puberty, Inhibin, FSH

J. Anim. Sci. 1991. 69:276-282

\footnotetext{
${ }^{1}$ Grateful appreciation is extended to James Dias for the gift of the FSH antisera, to L. E. Reichert for the iodination grade FSH, and to the NIADDK for providing the FSH reference preparation.

${ }^{2}$ Dept. of Dairy and Anim. Sci.

${ }^{3}$ To whom reprint requests should be addressed.

${ }^{4}$ USDA, ARS, Roman L. Hruska, U.S. Meat Anim. Res. Center.

${ }^{5}$ Mention of a trade name, proprietary product or specific equipment does not constitute a guarantee or warranty of the product by the USDA and does not imply its approval to the exclusion of other products that may also be suitable.

Received February 7, 1990.

Accepted June 27, 1990.
}

\section{Introduction}

Factors that control the secretion of FSH prior to puberty are of considerable interest because FSH appears to be an important signal both to initiate growth and development of the gonad (Griswold et al., 1977; Solari and Fritz, 1978; Orth, 1984) and to stimulate the secretion of inhibin (INH) (Steinberger and Steinberger, 1976; deJong et al., 1978; Feig et al., 1980). The protein INH has been implicated in the control of FSH secretion in adult and prepubertal mammals. The patterns of circulating FSH and $\mathbb{N H}$ in the developing 
bull have been described, but reports are conflicting (McCarthy et al., 1979; Amann and Schanbacher, 1983; Miyamoto et al., 1989).

Administration of estradiol $\left(\mathbf{E}_{2}\right)$ prevents compensatory testicular growth (Schanbacher et al., 1987). In addition, in ruminants, $E_{2}$ (Schanbacher et al., 1987) and INH (Schanbacher, 1988) inhibit the secretion of FSH. The relative importance of $E_{2}$ and inhibin in the control of FSH during the infantile period of life in bulls is not known.

The objectives of our first study were to describe the pattern of plasma INH in developing Holstein bulls from 4 through 36 wk of age, and to determine temporal relationships among plasma INH, FSH and testosterone $\left(\mathbf{T}_{4}\right)$ and changes in testicular length. The objective of the second study was to determine the effect(s) of castration and(or) exogenous $\mathrm{E}_{2}$ on plasma concentrations of INH and FSH from 3 through $14 \mathrm{wk}$ of age in bulls.

\section{Materials and Methods}

Experiment 1. Twenty Holstein bulls were obtained at 3 to $5 \mathrm{~d}$ of age and transported to the Dairy Breeding Research Center, where they were raised according to previously published guidelines (Curtis and Amann, 1981). At 14-d intervals from 4 through 36 wk of age, samples of blood were collected by jugular venipuncture; plasma was harvested and stored at $-20^{\circ} \mathrm{C}$ for later determination of INH, FSH and $\mathrm{T}_{4}$ by RIA. At these same 14-d intervals, testicular length was measured using a caliper.

Experiment 2. To determine the effects of castration and estrogen treatment on FSH and INH, we assayed samples of plasma from a study designed to investigate the effects of estrogen on secretion of $\mathbf{L H}$ and testicular development (Deaver et al., 1988). Nineteen Holstein bulls were obtained and raised as previously described (Curtis and Amann, 1981). Calves were assigned at random to one of four treatments: 1) intact $(n=5), 2)$ intact and $\left.E_{2}(n=4), 3\right)$ castrated $(n=5)$ or 4$)$ castrated and $E_{2}(n=5)$. Castrations were performed and(or) a 30-mm implant containing $\mathrm{E}_{2}$ (Compudose $\left.{ }^{\mathrm{TM}}\right)^{6}$ was inserted into the right

\footnotetext{
6200-d implant, Elanco Products Company, Indianapolis, IN.

${ }^{7}$ Costa Mesa, CA.
}

ear at 7.5 wk of age. Blood estradiol concentrations were reported previously (Deaver et al., 1988). Between 3 and 14 wk of age, samples of blood were collected weekly by jugular venipuncture; plasma was harvested and stored at $-20^{\circ} \mathrm{C}$ until it was assayed for INH and FSH.

Testosterone RIA. Immunoreagents for the testosterone assay were obtained from ICN Biomedicals, Inc. ${ }^{7}$ The antibody dilution used bound an average of $57 \pm .2 \%$ of the [125 I]TME-testosterone $(14,759 \pm 141 \mathrm{dpm} /$ tube). The average slope and y-intercept of the assay standard curve were -.6312 and 0.1121 , respectively. The within- and between-assay CV were $4.12 \%$ and $5.99 \%$, respectively. The mass of standard required to displace $50 \%$ of the tracer was $149.6 \mathrm{pg}$. The mass of the lowest standard was $2.5 \mathrm{pg}$ per tube; this mass was used as the lower limit of detection. Cross-reactivity was $3.4 \%$ for $5 \alpha$-dihydrotestosterone, $2.2 \%$ for $5 \alpha$-androstane$3 \alpha, 17 \beta$-diol and $2.0 \%$ for 11 -oxotestosterone. All other cross-reactivities were less than $1.0 \%$.

Inhibin RIA. A single assay was used to quantify concentrations of INH for samples in Exp. 1 and 2. This assay has been described previously by Schanbacher (1988). Briefly, $200 \mu \mathrm{l}$ of plasma were incubated with $400 \mu \mathrm{l}$ of BDS-INH3 antiserum diluted 1:60,000 and $10,000 \mathrm{cpm}$ of ${ }^{[125}$ ]porcine inhibin $\alpha(1-30)$ overnight in phosphate-buffered saline assay buffer at room temperature. Approximately 18 h later, $100 \mu \mathrm{l}$ of a preprecipitated second antibody complex were added to each tube, mixed, incubated for $1 \mathrm{~h}$, then centrifuged to determine precipitated counts. Concentrations of inhibin were expressed in picomoles per liter ( $\mathrm{p} M$ ) plasma. Sensitivity of the assay was less than $12.5 \mathrm{pM}$ and the intra-assay $\mathrm{CV}$ was less than $10 \%$.

Follicle-Stimulating Hormone RIA. The FSH assay was pattemed after that of Acosta et al. (1983) with some modifications. The assay used LER-1976-A2 oFSH as the iodinated preparation, oFSH-AFP 5679C as the standard and JAD-17-679 anti-oFSH as the first antibody. The antibody dilution used bound an average of $20 \%$ of the [ ${ }^{125}$ ] $\mathrm{oFSH}$ LER-1976-A2, and the average slope and yintercept of the assay standard curve were -.9054 and 2.3048 , respectively. The withinand between-assay $\mathrm{CV}$ were $5.8 \%$ and $6.9 \%$, respectively, and the mass of standard required 
to displace $50 \%$ of the tracer was $350 \mathrm{pg}$. Sensitivity of the assay was $50 \mathrm{pg}$ per tube.

Statistical Analysis. Data for plasma concentrations of hormones and testicular length were analyzed using the General Linear Model procedure of SAS for repeated measures in time (Freund and Littell, 1981). Age was the independent variable in Exp. 1. For Exp. 2, treatment (castration or estradiol) was used as the main-plot effect, and effects of age and the treatment $\times$ age interaction were sub-plot effects.

\section{Results}

Experiment 1. Plasma concentrations of INH changed with age $(P<.0001$, Figure 1A) during the 32-wk experimental period. From 4 until 8 wk of age, INH remained constant, then it increased from $120 \mathrm{pM}$ to $202 \mathrm{p} M$ between 8 and $12 \mathrm{wk}$. After $12 \mathrm{wk}$, INH decreased to 90 $\mathrm{p} M$ at 36 wk of age. Plasma concentrations of FSH also changed with age $(P<.02)$. Between 4 and $10 \mathrm{wk}$ of age, plasma concentrations of FSH increased from $.32 \mathrm{ng} / \mathrm{ml}$ to $.43 \mathrm{ng} / \mathrm{ml}$; increases in FSH appeared to precede the initial rise in plasma INH. Between 10 and 12 wk, the period of rapid increase in plasma INH, FSH declined from $.43 \mathrm{ng} / \mathrm{ml}$ to $.33 \mathrm{ng} /$ $\mathrm{ml}$. The second increase in plasma FSH commenced after 12 wk of age, and a mean concentration of $.55 \mathrm{ng} / \mathrm{ml}$ was attained at 20 wk. Thereafter, FSH remained between .42 and $.53 \mathrm{ng} / \mathrm{ml}$ as plasma INH decreased through 32 wk of age.

As shown in Figure 1B, testicular length increased with age $(P<.0001)$. Before 10 wk of age, testes were small and scrotal skin was quite variable in thickness, making accurate measurement of testicular length difficult. At $10 \mathrm{wk}$, testicular length was $3.75 \pm .07 \mathrm{~cm}$. No change in testicular length was noted between 10 and 14 wk. After 14 wk, testicular length increased linearly $(r=.99)$ and reached $9.64 \pm$ $.10 \mathrm{~cm}$ at $36 \mathrm{wk}$ of age. The initial increase in testicular length occurred coincidently with the second rise in plasma FSH.

Age-related changes in plasma $T_{4}$ are shown in Figure 1C. Concentrations of plasma $\mathrm{T}_{4}$ increased with age $(P<.0001)$. Between 4 and 12 wk of age, plasma $T_{4}$ remained below $200 \mathrm{pg} / \mathrm{ml}$ and appeared to rise initially at 14 wk of age, reaching $1.26 \pm .21 \mathrm{ng} / \mathrm{ml}$ by 20 wk. Plasma $\mathrm{T}_{4}$ continued to increase after 20 wk of age and averaged $3.29 \pm .44 \mathrm{ng} / \mathrm{ml}$ at 36 wk. Initial increases in both concentrations of plasma $T_{4}$ and testicular length appeared to occur simultaneously with the second rise in plasma FSH at 14 wk of age.

Experiment 2. Plasma concentrations of FSH for calves intact or intact and implanted with $\mathrm{E}_{2}$ at $7.5 \mathrm{wk}$ are shown in Figure $2 \mathrm{~A}$. In all bulls, concentrations of plasma FSH increased between wk 3 and 7 from $.26 \pm .03 \mathrm{ng} /$ $\mathrm{ml}$ to $.48 \pm .04 \mathrm{ng} / \mathrm{ml}$. Concentrations of plasma FSH averaged $.40 \pm .07 \mathrm{ng} / \mathrm{ml}$ between 8 and 14 wk of age in intact bulls. For bulls treated with $E_{2}$, concentrations of plasma FSH decreased to $.20 \pm .04 \mathrm{ng} / \mathrm{ml}$ following insertion of the implant and remained low throughout $14 \mathrm{wk}$, averaging $.18 \pm .04 \mathrm{ng} / \mathrm{ml}$.

Plasma concentrations of FSH for calves castrated or castrated and implanted with $E_{2}$ at 7.5 wk of age are shown in Figure 2B. Plasma FSH increased $(P<.0001)$ after castration, reaching $3.66 \pm .46 \mathrm{ng} / \mathrm{ml}$ by wk $13(5.5 \mathrm{wk}$ post-castration). For calves castrated and implanted with $\mathrm{E}_{2}$ at 7.5 wk of age, concentrations of plasma FSH decreased to $.26 \pm .05 \mathrm{ng} /$ $\mathrm{ml}$ at $8 \mathrm{wk}$ and remained suppressed throughout 14 wk, averaging $.22 \pm .05 \mathrm{ng} / \mathrm{ml}$.

Plasma concentrations of INH for intact calves or calves intact and implanted with $E_{2}$ are shown in Figure 3A. Between 3 and 5 wk of age, concentrations of plasma INH increased from $183 \pm 9 \mathrm{p} M$ to $259 \pm 17 \mathrm{p} M$ and average $255 \pm 15 \mathrm{p} M$ at wk 7 . For intact bulls, concentrations of plasma $\mathbb{N N H}$ continued to rise slowly reaching $313 \pm 56 \mathrm{pM}$ by $13 \mathrm{wk}$ of age. After 8 wk of age, concentrations of plasma INH were lower in $E_{2}$-treated bulls than in unimplanted bulls (treatment $\times$ age; $P<.001$ ).

Plasma concentrations of INH for bull calves castrated or castrated and implanted with $E_{2}$ are shown in Figure 3B. After castration, concentrations of plasma INH decreased and were $97 \pm 11$ and $96 \pm 27 \mathrm{pM}$ throughout wk 14 for castrated and castratedimplanted calves, respectively. Concentrations of INH were similar for nonimplanted and implanted calves following castration.

\section{Discussion}

Bull calves secreted significant quantities of INH into plasma during the infantile and prepubertal stages of development; high plasma concentrations of immunoreactive INH were observed between 8 and $14 \mathrm{wk}$ of age in the bulls used for Exp. 1. In addition to the 

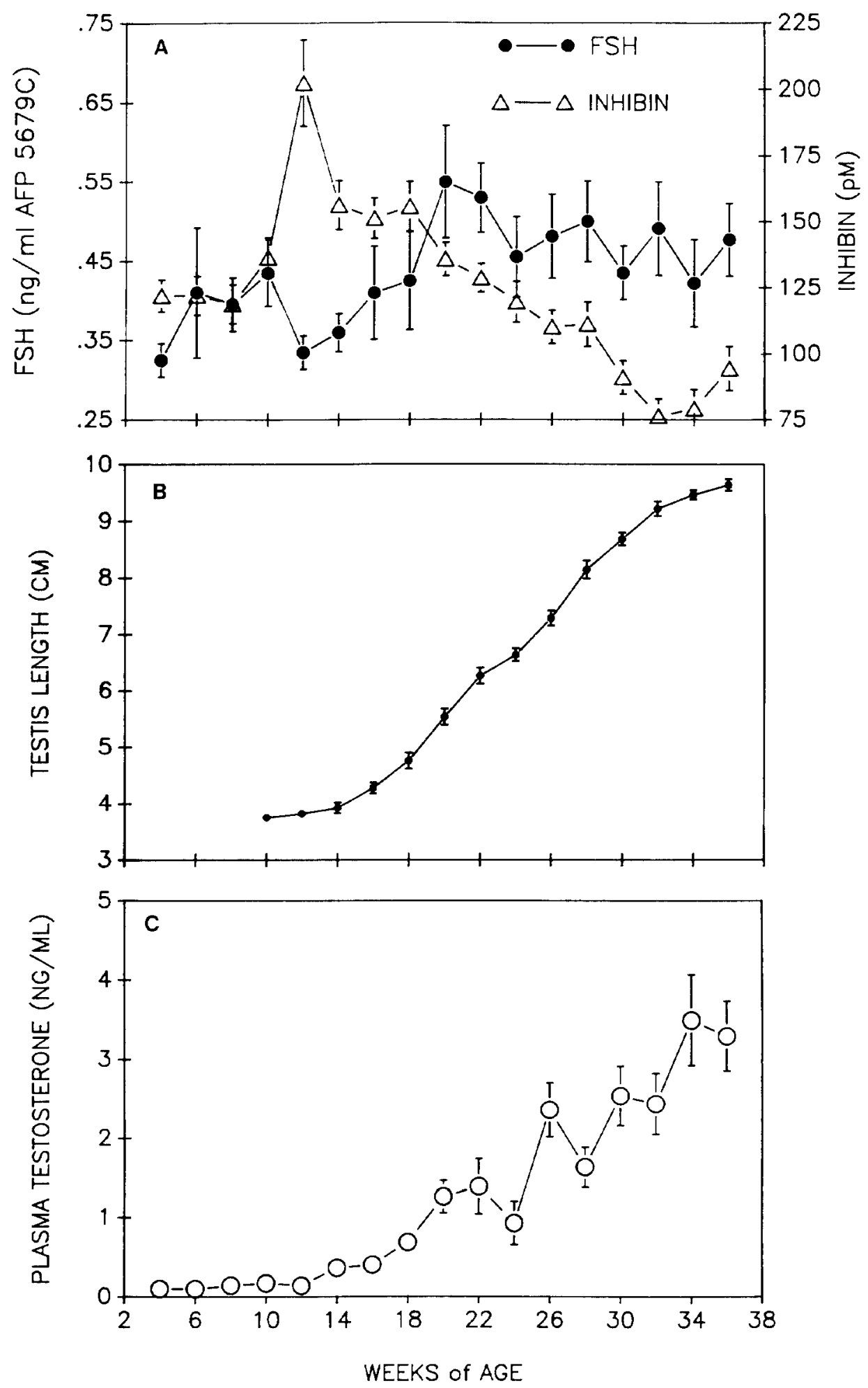

Figure 1. Temporal relationships between A) plasma concentrations of FSH and INH, B) testis length and C) plasma concentrations of $T_{4}$ for the bulls used in Exp. 1, from 4 through 36 wk of age. 


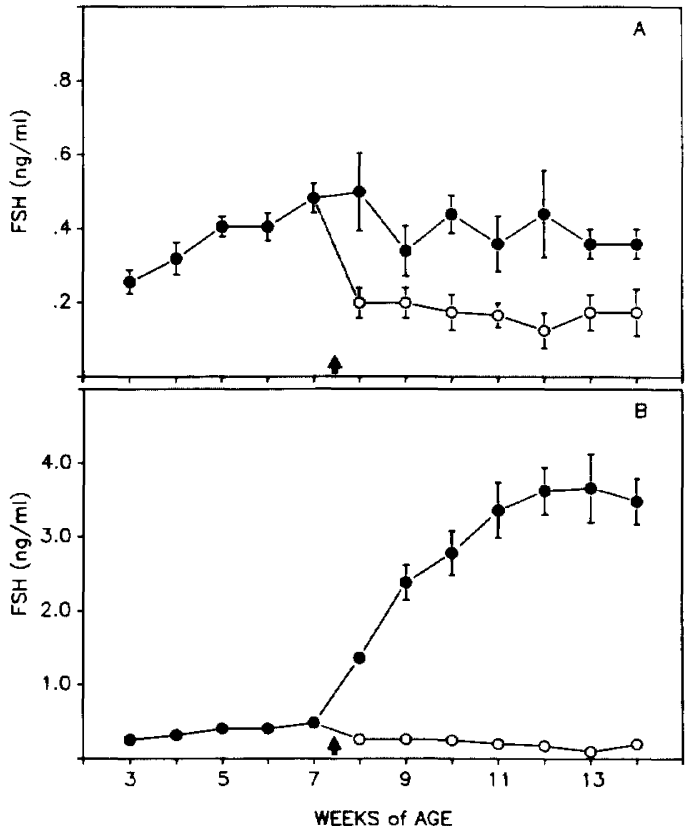

Figure 2. Plasma concentrations of FSH during the period of 3 through 14 wk of age for bulls: A) intact (O) or intact and implanted with estradiol (O) at 7.5 wk of age, and B) castrated (O) or castrated and implanted with estradiol (0) at 7.5 wk of age in Exp. 2. The age at castration and estradiol implantation is indicated by the arrows. Note the difference in the scaling of the $y-A x i s$ between panels $A$ and $B$.

testis there are several sources of INH. Even though Sertoli cells are considered one of the major intratesticular sources of INH (Steinberger et al., 1983), mRNA for the $\alpha, \beta A$ and $\beta B$ subunits are expressed in a variety of tissues, including the placenta, pituitary and brain (Meunier et al., 1987). Veeramachaneni et al. (1989) demonstrated, by use of immunocytochemical methods, the presence of inhibin within the ovine testis and excurrent duct system, and Miyamoto et al. (1989) demonstrated, by using a bioassay for bovine follicular fluid inhibin, the presence of inhibin within the testis of immature beef bulls. In Exp. 1, we observed elevated plasma INH during the period of development when the Sertoli cell is considered to be undifferentiated (Curtis and Amann, 1981). Also, high concentrations of INH were observed for intact calves but not for castrated calves between 8 and 14 wk of age in Exp. 2. These observations may be interpreted to indicate that the testis is a major source of INH in the developing bull.

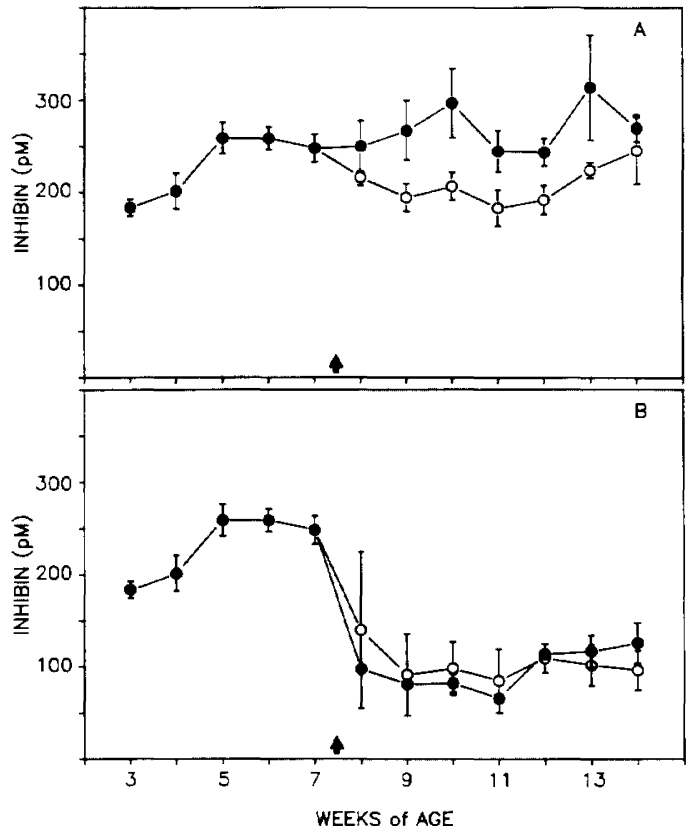

Figure 3. Plasma concentrations of INH during the period of 3 through 14 wk of age for bulls: A) intact (O) or intact and implanted with estradiol $(0)$ at 7.5 wk of age, and B) castrated (O) or castrated and implanted with estradiol (0) at 7.5 wk of age in Exp. 2. The age at castration and estradiol implantation is indicated by the arrows.

Follicle-stimulating hormone appears to be the gonadotropin that binds specifically to the bovine Sertoli cell (Schanbacher, 1979). In bull calves between 4 and 10 wk of age, the increase in concentrations of FSH may induce formation or recruitment of its own receptors on the non-differentiated Sertoli cells (Smith and Ojeda, 1986). This recruitment of receptors for FSH could initiate biochemical changes within Sertoli cells, including mitosis, and prepare these cells for the onset of spermatogenesis (Griswold et al., 1976; deJong et al., 1978; Feig et al., 1980) when signalled by the second rise in plasma FSH observed between 12 and 20 wk of age. In the Holstein bull calf, Curtis and Amann (1981) observed that the numbers of Sertoli cells per testis began to increase sometime between 16 and 20 wk of age, soon after the age at which the second rise in plasma FSH was observed in the present study (Exp. 1).

In bulls, the transition from the infantile to the prepubertal stages of development occurs during the period between 8 and $14 \mathrm{wk}$ of age 
(Amann, 1983) and is marked by an increase in $L H$ pulse frequency and amplitude (Amann, 1983; Deaver and Peters, 1988). During this period, concentrations of plasma INH increase rapidly, and administration of the opioid antagonist naloxone results in elevated plasma LH (MacDonald et al., 1990) but not FSH (our unpublished observations). Therefore, high plasma concentrations of INH may selectively regulate the secretion of FSH at this time.

For bulls in the present study (Exp. 1), the second rise in plasma FSH as well as the initial increases in plasma $T_{4}$ and testis length occurred at or immediately after $14 \mathrm{wk}$ of age. In Exp. 2, castrating bull calves at 7.5 wk of age resulted in an immediate decrease in plasma concentrations of INH and increased FSH; however, exogenous $E_{2}$ prevented the increase in plasma FSH in castrate bulls. This suggests that mechanisms in addition to INH regulate secretion of FSH in the immature bull (Schanbacher, 1981). In intact bull calves implanted with $E_{2}$, concentrations of plasma FSH were suppressed more than in castrate or intact calves, and concentrations of plasma INH did not appear to increase, as was observed in intact, untreated calves. This may indicate a basal secretory rate of INH by the immature Sertoli cell that is stimulated by some mechanism(s) other than increasing concentrations of FSH at this period (Steinberger et al., 1983; Franchimont et al., 1984).

In conclusion, after $10 \mathrm{wk}$ of age in bull calves, an inverse relationship was found to exist between plasma concentrations of INH and FSH. The timing of the age-related changes in plasma INH and FSH may be important for signaling the Sertoli cells to divide, and for determining the adult testis size. Adult testis size determines, in part, the number of germ cells and daily sperm production rate possible by the breeding sire. Immature testis may be a major source of INH in the developing bull because castration at 7.5 wk of age decreased plasma INH.

\section{Impllcations}

Knowledge of endocrine events and the relationships between the hypothalamus, pituitary and testis in the developing bull may aid researchers in devising methods to modify the numbers of Sertoli cells, and possibly adult daily sperm production. Understanding of endocrine events in the normally developing animal may aid in our understanding of abnormal development. Increases in peripheral concentrations of FSH preceded increases in testicular size in bulls. Thus, manipulations that enhance the secretion of FSH might enhance the development of the testis.

\section{Literature Clted}

Acosta, B., G. K. Tamavsky, T. E. Platt, D. L. Hamernik, J. L. Brown, H. M. Schoenemann and J. J. Reeves. 1983. Nursing enhances the negative effect of estrogen on LH release in the cow. J. Anim. Sci. 57:1530.

Amann, R. P. 1983. Endocrine changes associated with the onset of spermatogenesis in Holstein bulls. J. Dairy Sci. 66:2602.

Amann, R. P. and B. D. Schanbacher. 1983. Physiology of male reproduction. J. Anim. Sci. 57(Suppl. 2):433.

Curtis, S. K. and R.P. Amann. 1981. Testicular development and establishment of spermatogenesis in Holstein bulls. J. Anim. Sci. 53:1645.

Deaver, D. R., J. D. Glass, D. M. Grieger and J. J. Reeves. 1988. Effects of estradiol on secretion of $\mathrm{LH}$, hypothalamic function and testicular development in bull calves. Domest. Anim. Endocrinol. 5:307.

Deaver, D. R. and J. L. Peters. 1988. Age-related changes in secretion of luteinizing hormone and metabolism of hypothalamic amines in bull calves prior to puberty. Biol. Reprod. 39:622.

deJong, F. H., R. Welschen, W. P. Hermans, S. P. Smith and H. Vandermolen. 1978. Effects of testicular and ovarian inhibin-like activity using in vitro and in vivo systems (rat). Int. J. Androl. 2(Suppl.):125.

Feig, L. A., A. R. Bellve, N. H. Erickson and M. Klagsburn. 1980. Sertoli cells contain a mitogenic peptide. Proc. Natl. Acad. Sci. USA 77:4774.

Franchimont, P., F. Croze, K. Henderson, M. T. HazeeHagelstein and M. J. Lecomte-Yerna. 1984. Regulation of inhibin secretion by granulosa cells in culture. In: M. R. Sairam and L. E. Atkinson (Ed.) Gonadal Proteins and Peptides and Their Biological Significance. p 127. World Scientific, Singapore.

Freund, R. J. and R. C. Littell. 1981. SAS for linear models. A guide to the ANOVA and GLM procedures. SAS Inst. Inc., Cary, NC.

Griswold, M., E. Mabby and I. B. Fritz. 1976. FSH stimulation of DNA synthesis in Sertoli cells in culture. Mol. Cell. Endocr. 4:139.

Griswold, M. D., A. Solari, P. S. Tung and I. B. Fritz. 1977. Stimulation by follicle-stimulating hormone of DNA synthesis and mitosis in cultured Sertoli cells prepared from testes of immature rats. Mol. Cell. Endocr. 7:151.

MacDonald, R. D., J. L. Peters and D. R. Deaver. 1990. Effect of naloxone on the secretion of LH in infantile and prepubertal Holstein bulls calves. J. Reprod. Fertil. 89:51.

McCarthy, M. S., H. D. Hafs and E. M. Convey. 1979. Serum hormone patterns associated with growth and sexual development in bulls. J. Anim. Sci. 49:1012.

Meunier, H., C. Rivier, R. M. Evans and W. Vale. 1988. Gonadal and extragonadal expression of inhibin $\alpha, \beta A$ and $\beta B$ subunits in various tissues predicts diverse functions. Proc. Natl. Acad. Sci. USA 85:247.

Miyamoto, A., M. Umezu, S. Ishii, T. Furusawa, J. Masaki, Y. Hasegawa and M. Ohta. 1989. Serum inhibin, FSH, 
LH and testosterone levels and testicular inhibin content in beef bulls from birth to puberty. Anim. Reprod. Sci. 20:165.

Orth, J. M. 1984. The role of follicle-stimulating hormone in controlling Sertoli cell proliferation in testes of fetal rats. Endocrinology 115:1248.

Schanbacher, B. D. 1979. Relationship of in vitro gonadotropin binding to bovine testes and the onset of spermatogenesis. J. Anim. Sci. 48:591.

Schanbacher, B. D. 1981. Importance of the episodic nature of luteinizing hormone secretion for normal development of the bovine testis during puberty: Interference with oestradiol-17 beta. J. Endocrinol. 88:393.

Schanbacher, B. D. 1988 . Radioimmunoassay of inhibin: serum responses to unilateral and bilateral orchidectomy. Endocrinology 123:2323.

Schanbacher, B. D., P. W. Fletcher and L. E. Reichert, Jr. 1987. Testicular compensatory hypertrophy in the hemicastrated calf: Effects of exogenous estradiol. Biol. Reprod. 36:1142.
Smith, S. S. and S. R. Ojeda. 1986. Neonatal release of gonadotropins is essential for development of ovarian follicle-stimulating hormone receptors. Biol. Reprod. 34:219.

Solari, A. J. and I. B. Fritz. 1978. The ultrastructure of immature Sertoli cells. Maturation-like changes during culture and the maintenance of mitotic potentiality. Biol. Reprod 18:329.

Steinberger, A., L. Seethalakshmi, H. Kessler and E. Steinberger. 1983. Sertoli cell factor. In: S. M. McCann and D. S. Dhindsa (Ed.) Role of Peptides and Proteins in Control of Reproduction. p 215. Elsevier, Amsterdam.

Steinberger, A. and E. Steinberger. 1976. Secretion of an fsh-inhibiting factor by cultivated Sertoli cells. Endocrinology 99:918.

Veeramachaneni, D.N.R., B. D. Schanbacher and R. P. Amann. 1989. Immunolocalization and concentrations of inhibin- $\alpha$ in the ovine testis and excurrent duct system. Biol. Reprod. 41:499. 